\title{
PERKEMBANGAN JEMAAT AHMADIYAH QADIANI DI WILAYAH MEDAN - ACEH, 1968-1998
}

\author{
THE GROWTH OF JEMAAT AHMADIYAH QADIANI IN \\ MEDAN-ACEH, 1968-1998
}

\author{
Yopi Rachmad \\ Peneliti pada Gebu Institute dan Guru SMA Negeri 6 Binjai \\ Pos-el:yopismantig@gmail.com
}

\begin{abstract}
This study aims to study determine the development of the Jemaat Ahmadiyya Qadiani in the Medan-Aceh in 1968-1998. This study use 2 methods and techniques of data collection. First, library method (Library Research) by books, articles, documents, newspapers, magazines and websites. The other method is Field Research (Field Research). From the research, it can be concluded that the development of Ahmadiyah Qadiani in Medan-Aceh during the New Order period has progressed relatively slowly, althought the Government's response is neutral. The Ahmadiyya Qadianis of Medan-Aceh has not been able to do much for the development of the community. This is related to the issuance of the fatwa of the Majleis Ulama Indonesia Sumatra Utara which stated that the Jemaat Ahmadiyya Qadiani is a group outside of Islam.
\end{abstract}

Keywords: jemaat, Ahmadiyah, Qadiani, and fatwa.

\begin{abstract}
ABSTRAK
Kajian ini bertujuan untuk melihat perkembangan dari Jemaat Ahmadiyah Qadiani di wilayah MedanAceh pada 1968-1998. Kajian ini menggunakan metode dan teknik pengumpulan data dengan studi pustaka dengan buku, artikel, dokumen, surat kabar, majalah dan situs website. Penulis juga melakukan penelitian lapangan. Penelitian ini mendapatkan kesimpulan bahwa perkembangan Ahmadiyah Qadiani di wilayah Medan-Aceh selama periode Orde Baru berkembang relatif lamban, walaupun respon pemerintah netral. Ahmadiyah Qadiani di Medan Aceh tidak mampu melakukan banyak hal terhadap perkembangan komunitasnya. Hal ini berhubungan dengan isu dari Majelis Ulama Indonesia Sumatra Utara yang menyatakan bahwa jemaat Ahmadiyah Qadiani merupakan sebuah kelompok di luar Islam.
\end{abstract}

Kata kunci: jemaat, Ahmadiyah, Qadiani, dan fatwa.

\section{A. PENDAHULUAN}

Munculnya Ahmadiyah Qadiani di daerah Qadian, India yang kemudian hari menyebar hampir ke seluruh dunia termasuk Indonesia, sudah barang tentu dilatarbelakangi oleh situasi dan kondisi India pada masa hidup Mirza Ghulam Ahmad (Zulkarnain: 2005:3). Perpecahan umat Islam menjadi alasan bagi Mirza Ghulam Ahmad untuk memunculkan sebuah gerakan yang bersifat Mahdistik, yang akan menjadi juru damai di tengah-tengah perpecahan itu. Sebagai pendiri Ahmadiyah Qadiani, Mirza Ghulam Ahmad berusaha untuk memperbaiki keadaan umat Islam India melalui perubahan pola pikir dalam 
memahami agama Islam yang disesuaikan dengan perubahan zaman. Melalui Jemaat Ahmadiyah Qadiani yang didirikannya pada 23 Maret $1889^{1}$ yang saat ini berpusat di London, Inggris, Mirza Ghulam Ahmad ingin melakukan perubahan tersebut.

Walaupun tidak dapat disebut sebagai perpecahan, kondisi yang cukup sulit juga terjadi di Indonesia. Tantangan zaman yang menghimpit umat Islam saat itu dapat disebutkan antara lain: umat Islam hampir di seluruh dunia - berada di bawah belenggu cengkeraman penjajahan, kebekuan pemikiran keagamaan, rendahnya mutu pendidikan. Belum lagi menyebut situasi umum umat Islam yang sangat mudah dijumpai di sana sini seperti kebodohan, keterbelakangan dan kemiskinan (Ali, 1971: 20). Dalam kondisi demikian, pemikiran untuk melepaskan diri dari jerat ketidakadilan yang tidak manusiawi dan merindukan pemimpin yang adil, hadir dalam masyarakat Indonesia yang majemuk. Ahmadiyah Qadiani, perlahan tapi pasti, muncul dengan semboyan" kecintaan pada semua orang, tanpa kebencian", melebarkan sayapnya di negeri beribu pulau, yakni Indonesia.

Pada awal tahun 1924, Imam Jemaat Ahmadiyah Qadiani, Mirza Basyiruddin Mahmud Ahmad, mengadakan lawatan panjang (muhibah) ke Barat (Eropa) guna menghadiri dan berpidato pada konferensi Agama-agama di London dan mengemukakan judul Ahmadiyyat of The True Islam (Ahmadiyah, Islam Sejati), dan kembali ke Qadian pada akhir bulan Juli 1924. Sepulangnya dari melakukan lawatan ke Barat tersebut, Mirza Basyiruddin Mahmud Ahmad menghadiri undangan para pelajar Indonesia yang menyelenggarakan "Tea

1 Sebagaimana terdapat dalam Mirza Ghulam Ahmad as. Nasihat Imam Mahdi \& Masih Mau'ud as mengenai Bai'at,(Jakarta : Jemaat Ahmadiyah Indonesia). Buku ini merupakan terjemahan dari sabda-sabda yang tercantum di dalam kitab-kitab "Malfuzhat" dan "Majmu Isytiharat" tahun 1888 .
Party" di Qadian. Dalam kesempatan itu, para pelajar dari Indonesia memohon agar Imam Jemaat Ahmadiyah Qadiani bersedia untuk menyebarkan cahaya Islam sejati ke Timur, khususnya ke Indonesia (Arsip Jemaat Ahmadiyah Indonesia. 1996: 2).

Untuk merealisasikan keinginan para pelajar dari Indonesia yang belajar di Qadian itu, maka pada bulan Agustus 1924, Jemaat Ahmadiyah Qadiani di Qadian mengirimkan mubaligh pertamanya yakni Maulana Rahmat Ali HA. OT. Mubaligh pertama jemaat Ahmadiyah Qadiani itu berangkat dari Qadian akhir bulan Juli 1925 dan tiba di Tapaktuan (Aceh) pada tanggal 2 Oktober 1925 - melalui Penang, Medan dan Sabang di Pulau Weh, Kotaraja (Banda Aceh). Pada awal kedatangannya, mubaligh pertama Ahmadiyah Qadiani ini diterima oleh masyarakat, karena sebelum kedatangannya, pelajar-pelajar Indonesia yang belajar di Qadian telah mengirimkan surat kepada masyarakat di Tapaktuan akan perihal kedatangan utusan imam Mahdi tersebut (Arsip Jemaat Ahmadiyah Indonesia. 1996:4). ${ }^{2}$ Penerimaan itu juga dikarenakan masyarakat mengira Jemaat Ahmadiyah Qadiani itu sama dengan Muhammadiyah, sehingga utusan Jemaat Ahmadiyah Qadiani itu dapat dengan leluasa menyebarkan pengaruhnya.

Dalam episode berikutnya, terjadi penolakan dan pemboikotan yang dilakukan oleh semua golongan. Penolakan dan pemboikotan ini disebabkan karena pemahaman Jemaat Ahmadiyah Qadiani yang dianggap sesat dan menyesatkan. Ahmadiyah terus dike-

2 Adapun pelajar-pelajar Islam yang belajar di Qadian tersebut antara lain : Abu Bakar Ayyub, Ahmad Nuruddin (Sumatera Thawalib, Parabek) dan Zaini Dahlan (Medan). Kemudian bertambah lagi beberapa lama setelah ketiga pemuda tersebut belajar di Qadian. Mereka berasal dari Sumatera, yakni : Mahmud (Padang Panjang), Muhammad Nur (Lubukpasung), Abdul Wahid (Tapaktuan), Samsuddin (Rengat), Samsuddin Rao-rao (Batusangkar), Moh. Jusyak (Sampur), Moh. llyas (Padang Panjang), Hajiuddin (Rengat), Abdul Aziz Shreef (Padang), Moh. Idris dan Abdul Samik (Padang Panjang). Jumlah mereka menjadi 19 orang. 
cam, ditolak dan diboikot. ${ }^{3}$ Kondisi tersebut membuat penulis merasa tertarik untuk melihat Jemaat Ahmadiyah Qadiani dan menuliskannya. Hal ini dimaksudkan untuk mengetahui perkembangan Jemaat Ahmadiyah Qadiani di Wilayah MedanAceh, karena sebagai lazimnya sebuah gerakan, tentunya Jemaat ini mengalami apa yang dinamakan sebagai fase pertumbuhan dan perkembangan hingga kepada kegiatankegiatan yang dilakukan, yang di dalamnya akan terlihat penerimaan maupun penolakan, baik dari pemerintah maupun masyarakat.

Latar belakang inilah yang menggerakkan penulis untuk mengangkat batang terendam dari sebuah sejarah gerakan pemikiran dan keagamaan yang telah lama ada di Indonesia.

Tulisan ini diharapkan memberikan informasi pada peneliti dan pembaca tentang Perkembangan Jemaat Ahmadiyah Qadiani di Wilayah Medan-Aceh 1968-1998 dan memberikan pengetahuan bagi peneliti dan pembaca studi tentang gerakan pemikiran dan keagamaan di Indonesia, serta menjadi acuan bagi peneliti lainnya untuk meneliti dalam waktu dan tempat berbeda serta masalah yang juga berbeda. Kajian ini lebih fokus membahas perkembangan Ahmadiyah Qadiani di wilayah Medan-Aceh 1968-1998.

Masuk dan berkembangnya Jemaat Ahmadiyah Qadiani ke wilayah MedanAceh tidak terlepas dari keyakinan masyarakat muslim wilayah tersebut tentang kemunculan Al-Mahdi yang akan membawa bangkitnya kembali Islam dari ketertinggalan di segala bidang. Hal ini penulis kemukakan setelah melakukan kajian pustaka terhadap beberapa buku yang berkaitan dengan masalah yang penulis teliti.

3 Lihat Surat Kabar Pergaoelan, 9 Agustus 1932.Lihat juga Pergaoelan, 19 Agustus 1932 Hal. 1 dan 23 Agustus 1932, Hal. 3.Dalam surat kabar ini termuat Komite antiAhmadiyah yang mendesak Jemaat Ahmadiyah Qadiani agar keluar dari Aceh karena dianggap sesat dan menyesatkan (salah). Pengumuman kesalahan Jemaat Ahmadiyah Qadiani tersebut dibeberkan di lapangan Mesjid Raya pada 20 Agustus 1932.
Kebangkitan kembali Islam mempunyai sejumlah argumen yang kuat di dalam buku karya Taufik Abdullah dan Sharon Siddique (Abdullah dan sharon Siddique, 1989: 7-8), yang menyatakan bahwa konsep ini merupakan suatu pandangan dari dalam, suatu cara di mana kaum muslimin melihat bertambahnya dampak agama di antara para penganutnya. Hal ini mengisyaratkan kesan bahwa Islam menjadi penting kembali, artinya memeroleh kembali prestise dan kehormatan dirinya. Lebih lanjut keduanya juga mengungkapkan bahwa kebangkitan kembali menunjukkan keadaan tersebut telah terjadi sebelumnya. Ada petunjuk bahwa dalam kebangkitan saat ini terdapat unsurunsur yang berkaitan dengan masa lalu. Dan sesungguhnya, masa kejayaan Islam dulu - jejak hidup dari Nabi Muhammad SAW dan para pengikutnya - memberi pengaruh besar terhadap pemikiran orang-orang yang menaruh perhatian pada jalan hidup Islam saat ini. Pada sisi yang lain, tantangan zaman berupa hegemoni barat menjadi latar belakang bagi keinginan untuk kebangkitan kembali Islam.

Keinginan untuk kebangkitan kembali Islam termaktub di dalam Al-Qur'an sebagai wahyu dan sejarah gemilang di masa lampau. Islam berarti menyerahkan diri kepada ajaran yang dikehendaki oleh Tuhan. Karenanya seorang Muslim berarti orang yang menyerahkan dirinya kepada kehendak Allah sebagaimana diterangkan di dalam AlQur'an itu.

Namun demikian, penyerahan ini tidak boleh diartikan dalam pengertian pasif, karena Al-Qur'an menyatakan bahwa kewajiban setiap Muslim adalah berusaha dengan sungguh-sungguh (jihad) untuk melaksanakan kehendak Tuhan itu.

Jhon J Donohve dan John L. Esposito dalam bukunya menjelaskan bahwa misi Universal untuk mengembangkan kerajaan Islam (Darul Islam) di seluruh dunia ini merupakan kekuatan pendorong bagi 
Muhammad dan umat Islam terdahulu untuk membentuk masyarakat religio-politik (ummat) di Madinah. Dengan pengalaman sejarah tersebut, umat Islam mengharapkan kebangkitan kembali Islam berikutnya (Donohve dan Esposito, 1989:xxxiii)

Jemaat Ahmadiyah Qadiani didirikan oleh Mirza Ghulam Ahmad pada tahun 1889 di Qadian, India (Brosur Jamaah Muslim Ahmadiyah). Setelah wafat, maka melalui pemilihan, terpilihlah sahabatnya Hakim Nuruddin, sebagai khalifatul Masih I, kemudian setelah wafat, maka melalui pemilihan terpilihlah putra Mirza Ghulam Ahmad, Mirza Basyiruddin Mahmud Ahmad sebagai Khalifatul Masih II. Setelah wafat, melalui pemilihan juga, terpilihlah cucunya, Mirza Nasyhir Ahmad sebagai Khaliful Masih III, berturut-turut kemudian cucu dan cicit beliau, Mirza Thahir Ahmad sebagai Khalifatul Masih IV dan Mirza Masroor Ahmad sebagai Khalifatul Masih V. ${ }^{4}$

Pada masa Mirza Basyiruddin Mahmud Ahmad, Khalifatul Masih II, Jemaat Ahmadiyah Qadiani masuk ke wilayah Sumatera. Sinar Islam menyebutkan bahwa pada tanggal 2 Oktober 1925 Mubaligh pertama Jemaat Ahmadiyah Qadiani yaitu Maulana Rahmat Ali HA.OT. tiba di Tapaktuan (Sinar Islam, 1976:12).

Tapaktuan adalah sebuah kota pelabuhan di pantai Barat Sumatera menghadap Lautan India di daerah propinsi Aceh. Pada tahun yang sama, tepatnya ketika mubaligh pertama Jemaat Ahmadiyah Qadiani masuk ke Sumatera, terjadi perlawanan hebat dari almarhum Tengku Angkasah di daerah Bakongan terhadap pemerintah kolonialis Belanda. Saat itu, Kontroleur Belanda memberikan imbauan agar Rahmat Ali mening-

$4 \quad$ Wawancara dengan Mubaligh Jemaat Ahmadiyah Qadian Medan-NAD, Ibnu Muhyiddin. Khalifatul Masih merupakan konsep yang digunakan di dalam Jemaat Ahmadiyah Qadiani untuk penyebutan kepada pemimpin mereka di London sebagai pengganti dari Mirza Ghulam Ahmad untuk melanjutkan misi Imam Mahdi di dunia. galkan Tapaktuan (Aceh), namun beliau menolak dengan keterangan bahwa kedatangan beliau di sini membawa misi Imam Mahdi dan orang-orang Aceh adalah sesama orang muslim dengan beliau. Akhirnya, dengan cara halus Gubernur Aceh memerintahkan beliau untuk berpindah, maka terpaksa beliau berpindah ke Padang (Sumatera Barat) pada tahun 1936.

Untuk menyebarkan ajaran Jemaat Ahmadiyah Qadiani di Medan, pada tahun 1930, Maulana Rahmat Ali HA. OT menunjuk Maulana Sadiq HA. Barakatullah, sedangkan Maulana Rahmat Ali, meneruskan perjalanannya sampai keluar Sumatera (Arsip Jemaat Ahmadiyah Indonesia. 1996: 5). Maka, menyebarlah Jemaat Ahmadiyah Qadiani di wilayah Medan, Sumatera Utara dengan berbagai kendala yang hampir sama seperti yang dialami di daerah Aceh yang telah lebih dahulu mendapat pengaruh dengan kedatangan Maulana Rahmat Ali HA. OT.

Metode Penelitian untuk mengumpulkan data mengacu pada metode penelitian sejarah yang ditulis oleh Gilbert J. Garraghan. Sumber-sumber sejarah dikumpulkan dengan menggunakan metode kepustakaan (library research) yaitu metode penelitian melalui telaah pustaka, berupa buku-buku, dokumen-dokumen dan tulisan-tulisan yang dikumpulkan yang berhubungan dengan masalah yang diteliti dan juga dengan penelitian lapangan (field reasearch).

Sumber-sumber yang digunakan oleh peneliti lebih kepada sumber-sumber lisan yang digali dari wawancara terhadap tokoh-tokoh Ahmadiyah yang hidup pada kurun waktu penelitian dan tokoh-tokoh Ahmadiyah saat ini. Untuk sumber tulisan sendiri, peneliti menggunakan sumber berupa buku-buku yang ditulis oleh Mirza Ghulam Ahmad dan buku-buku yang dikeluarkan oleh Jemaat Ahmadiyah Qadiani sendiri dan buku-buku yang terkait dengan Ahmadiyah lainnya. 
Penelitian Lapangan (field research) juga dilakukan oleh peneliti, yaitu metode penelitian melalui observasi langsung ke lapangan di beberapa tempat dengan melakukan wawancara secara langsung.

\section{B. HASIL DAN BAHASAN}

\section{Perkembangan Jemaat Ahmadiyah Qadiani di Wilayah Medan-Aceh, 1968-1998}

\section{a. Jemaat Ahmadiyah Qadiani di Wilayah Medan-Aceh}

Salah satu konsekuensi yang tidak dapat dihindarkan dalam kelompok yang semakin membesar adalah diferensiasi yang semakin tinggi. Seperti Spencer, Durkheim dan para ahli teori klasik lainnya di abad kesembilan belas, Simmel mengakui bahwa (Johnson, 1986:280). :

\begin{abstract}
"Perubahan masyarakat secara evolusi jangka panjang dari sistem kecil yang sederhana yang terbentuk dari elemen-elemen yang homogen menjadi sistem besar yang kompleks yang terbentuk dari unsur-unsur yang heterogen. Diferensiasi membantu memberik-an dasar alternatif bagi pembentukan kelompok dan dengan demikian untuk sebagian membebaskan individu dari dominasi suatu struktur sosial yang bersifat monolitis".
\end{abstract}

Kita dapat melihat fenomena ini di dalam Islam, di mana saat itu, merupakan sebuah perahu besar yang dinaiki oleh banyak kelompok-kelompok kecil, yang tidak memiliki struktur sosial yang monolitis. Setelah kejatuhan kekhalifahan Turki Usmani, umat Islam dalam perpecahan.

Heterogenitas yang semakin meningkat memunculkan alternatif-alternatif dengan keinginan untuk memisahkan diri dari ikatan yang ada. Hal ini seperti yang diungkapkan oleh Simmel bahwa :
“Dasar yang paling awal dan paling primitif untuk pembentukan kelompok selain keluarga adalah kedekatan geografis semata-mata. Tetapi karena heterogenitas semakin meningkat, dasar-dasar alternatif pembentukan kelompok berdasarkan ikatan sosial dan kepentingan yang sama, dengan mana memisahkan dirinya dari orang lain dalam daerah geografis yang sama itu, serta memungkinakan dibentuknya ikatan sosial yang mengatasi daerah-daerah geografis itu"(Johnson, 1986:280).

Kepentingan bersama sebagai dasar pembentukan kelompok menuntut penggunaan kriteria rasional; artinya, individu memilih orang lain dengan siapa dia berasosiasi atas dasar suatu perkiraan rasional mengenai kepentingan objektif daripada hanya sekedar kedekatan tempat tinggal.

Berkaitan dengan Jemaat Ahmadiyah Qadiani, terbentuknya jemaat ini merupakan bentuk dari heterogenitas yang semakin meningkat, di mana individu yang tergabung di dalam Jemaat ini merupakan individu-individu yang memiliki keyakinan yang sama yakni pintu kenabian akan senantiasa terbuka, sehingga Mirza Ghulam Ahmad adalah Nabi, Al-Mahdi, Isa AlMasih dan Krysna bagi masyarakat Hindu, yang dilandasi oleh kepentingan yang sama bagi kebangkitan kembali Islam setelah keruntuhan Kekhalifahan Usmani. Pemahaman ini berbeda dengan sebagian umat Islam lainnya, yang menganggap pemahaman Jemaat Ahmadiyah Qadiani adalah sebuah kesalahan.

Hal inilah yang menjadi dasar bagi terbentuknya Jemaat Ahmadiyah, sehingga pada kesempatan berikutnya, mencoba untuk berkembang di wilayah Medan-Aceh sebagai sebuah gerakan pemikiran dan keagamaan.

Ahmad Sujanto dalam bukunya mengungkapkan bahwa "perkembangan merupakan suatu perubahan yang bersifat terpola, teratur dan terorganisasi dan dapat 
diprediksi" (Sujanto, 1985:10). Sebagai sebuah organisasi, Jemaat Ahmadiyah Qadiani juga mengalami fase pertumbuhan dan perkembangan, yang pada akhirnya melakukan kegiatan-kegiatan yang berkaitan dengan misi yang diembannya. Proses yang dialami oleh Jemaat Ahmadiyah Qadiani ini merupakan suatu yang terpola, teratur, dan terorganisir.

Jemaat Ahmadiyah Qadiani adalah sebuah gerakan pemikiran dan keagamaan yang sejak beberapa abad yang lalu terusmenerus bekerja dalam bidang tabligh dan penyebaran Islam sesuai dengan pemahaman yang mereka pahami di seluruh dunia. Landasan Jemaat ini diletakkan pada akhir abad yang lalu oleh Mirza Ghulam Ahmad Qadiani as (1835-1908) (Ahmad, 1984: 3). ${ }^{5}$

Setelah beliau wafat, di dalam Jemaat ini berlaku sistem khilafat. Berturut-turut Imam Jemaat Ahmadiyah ini silih berganti, mulai dari Hakim Nuruddin, sebagai khalifatul Masih I, kemudian setelah wafat, maka melalui pemilihan terpilihlah putra beliau, Mirza Basyiruddin Mahmud Ahmad sebagai Khalifatul Masih II. Setelah wafat, melalui pemilihan juga, terpilihlah cucu beliau, Mirza Nasyhir Ahmad sebagai Khalifatul Masih III, berturut-turut kemudian cucu dan cicit beliau, Mirza Thahir Ahmad sebagai Khalifatul Masih IV dan Mirza Masroor Ahmad sebagai Khalifatul Masih V (wawancara dengan Ibnu Muhyiddin, Mei 2007).

Di dalam struktur di tiap wilayah menggunakan istilah mubaligh, yang memimpin pergerakan Ahmadiyah. Mubaligh ini dipilih dengan terlebih dahulu mendapatkan pendidikan formal di lembaga-lembaga pendidikan Mubaligh Ahmadiyah. Para mubaligh inilah yang akan memimpin berbagai ke-

5 Buku ini merupakan karangan Hadhrat Mirza Ghulam Ahmad yang dialihbahasakan oleh, Mubaligh Jemaat Ahmadiyah Qadiani Wilayah Sumut-Aceh 1994-1995, dan Mubwil Sumbagut. giatan Ahmadiyah di tiap-tiap wilayah di seluruh dunia.

Charles J. Keating mengemukakan pengertian kepemimpi-nan sebagai berikut :

"Kepemimpinan merupakan suatu proses dengan berbagai cara memengaruhi orang lain atau kelompok orang untuk mencapai tujuan bersama".

Sementara E.K. Imam Munawir membagi dua jenis kepemimpinan yaitu :

1. kepemimpinan formal, yaitu orang yang secara resmi diangkat dalam jabatan kepemimpinan yang teratur dalam suatu organisasi.

2. kepemimpinan informal, yaitu kepemimpinan yang tidak mempunyai dasar pengangkatan resmi.

Jemaat Ahmadiyah Qadiani adalah merupakan organisasi yang diduga menggunakan jenis kepemimpinan formal karena mubaligh wilayah ditunjuk melalui pengangkatan secara resmi oleh pimpinan Jemaat Ahmadiyah Qadiani Indonesia. Seorang mubaligh yang ditunjuk secara resmi oleh Jemaat Ahmadiyah Qadiani dianggap sebagai utusan langsung Khalifatul Masih untuk menyampaikan perihal kedatangan Imam Mahdi di mana saja mereka diutus.

Dengan penunjukan ini, setiap mubaligh diharapkan meluangkan seluruh waktunya untuk memimpin dan menyampaikan pemikiran Jemaat Ahmadiyah Qadiani di mana pun mereka diutus. Agar kepemimpinan para mubaligh ini berjalan bersesuaian dengan harapan yang diinginkan, maka Jemaat Ahmadiyah Qadiani memberikan tunjangan dan tempat tinggal yang memungkinkan kepada setiap mubaligh.

Pada masa Khalifatul Masih II Mirza Basyiruddin Mahmud Ahmad, Jemaat Ahmadiyah Qadiani masuk ke Sumatera. Mubaligh pertama Jemaat Ahmadiyah 
Qadiani yang datang ke Sumatera adalah Maulana Rahmat Ali HA.OT.

Wilayah pertama yang disinggahi Maulana Rahmat Ali HA.OT adalah Tapaktuan, Aceh sebuah wilayah di bagian pantai barat Sumatera. Hal ini merupakan sebuah kenyataan yang dimungkinkan, karena wilayah ini bersinggungan langsung dengan lautan Hindia. Kita dapat melihat bahwa kedekatan wilayah ini dengan pantai, menjadi faktor pendukung daerah ini disinggahi pertama kali oleh penduduk asing, dalam hal ini Mubaligh Jemaat Ahmadiyah Qadiani.

Dalam perkembangan selanjutnya, Jemaat Ahmadiyah menyebar dari wilayah Aceh ke wilayah tetangganya yaitu Medan, Sumatera Utara. Perlahan-lahan, Jemaat Ahmadiyah menyebar ke wilayah Medan dan sekitarnya.

Pada masa kolonialisme Belanda, aroma pergerakan pemikiran ini tidak terasa. Jemaat ini seolah-olah hilang dari peredaran di wilayah Medan-Aceh. Hanya ada beberapa bukti yang menjelaskan keberadaan Jemaat Ahmadiyah Qadiani di Wilayah MedanAceh.

Salah satu bukti keberadaan Jemaat ini terindikasi di dalam dua surat kabar yang terbit di Aceh, yaitu surat kabar Pergaoelan tanggal 9 Agustus 1932, 19 Agustus 1932, 23 Agustus 1932 dan surat kabar Pedoman Masyarakat tanggal 20 Januari 1936, seperti yang telah dijelaskan sedikit di dalam bab sebelumnya.

Di dalam Surat kabar Pergaoelan memuat komite Anti-Ahmadiyah yang mendesak Jemaat Ahmadiyah Qadiani agar keluar dari Aceh karena pemikiran dan ajaran-ajaran Jemaat Ahmadiyah Qadiani yang bertentangan dengan pemahaman yang selama ini telah terbangun di dalam paradigma pemikiran umat Islam di daerah ini. Akhirnya, semua yang dianggap sebagai kesalahan Jemaat Ahmadiyah Qadiani dibeberkan di lapangan Mesjid Raya pada tanggal 20 Agustus 1932.

Surat kabar Pedoman Masyarakat, juga memperlihatkan betapa masyarakat Aceh menolak Jemaat Ahmadiyah Qadiani (Pedoman Masyarakat, 20 Januari 1936). Lebih ekstrim lagi, Jemaat Ahmadiyah Qadiani dianggap sebagai agent British. Hal ini terjadi karena pengalaman sejarah dan tulisantulisan dari pendiri Jemaat Ahmadiyah Qadiani yang terlihat secara nyata menjalin kedekatan dengan pihak Inggris, sehingga diduga menjadi agen Inggris yang ketika itu sedang memperluas kekuasaannya. Oleh karena itu, orang-orang yang dianggap sebagai ulama, bahu-membahu dengan masyarakat dan pemerintah Belanda di dalam komite Anti-Ahmadiyah. Komite ini dibentuk untuk mencegah perkembangan Jemaat Ahmadiyah Qadiani di Aceh. Satu hal yang aneh, bahwa Belanda "ikut-ikutan" melawan Jemaat Ahmadiyah Qadiani. Hal ini berada di luar nalar, sehingga terlihat indikasi untuk memecah belah umat Islam.

Di samping itu, keikutsertaan Belanda di dalam komite ini dapat diartikan sebagai bentuk perlawanan yang cenderung terkait dengan masalah politik. Belanda sepertinya menganggap Jemaat Ahmadiyah sebagai sebuah ancaman yang begitu berarti sehingga perkembangannya di wilayah ini harus dicegah, mengingat pengalaman sejarah Jemaat Ahmadiyah Qadiani yang terlalu dekat dengan pemerintahan Inggris, sehingga menciptakan kekhawatiran Belanda apabila Jemaat Ahmadiyah Qadiani mengalami perkembangan di wilayah Aceh. Genderang perang ditabuh oleh orangorang yang dianggap ulama dan masyarakat yang disponsori oleh Belanda yang takut hegemoninya atas wilayah ini hilang untuk selama-lamanya. Sebuah gambaran sejarah yang begitu mempesona melihat tanggapan atau respon yang cukup berarti terhadap perkembangan Jemaat Ahmadiyah Qadiani di wilayah Aceh. Belanda mengambil ke- 
sempatan di dalam perseteruan antara Jemaat Ahmadiyah Qadiani dengan masyarakat Aceh untuk mengukuhkan eksistensinya.

Perkembangan Ahmadiyah Qadiani di Wilayah Aceh berdasarkan bukti atau sumber sejarah yang masih ada hanya sampai ketika Maulana Rahmat Ali HA. OT, mubaligh yang ditugaskan Jemaat Ahmadiyah Qadiani di India keluar dari wilayah ini untuk selanjutnya pindah ke wilayah sekitarnya.

Ali Mukhayat dalam bukunya menjelaskan bahwa muncul perdebatan antara Maulana Rahmat Ali dengan masyarakat Aceh awal-awal masuknya Jemaat Ahmadiyah Qadiani di wilayah Aceh. Perdebatan ini terjadi di rumah Mamak Gamuk pada akhir Desember 1925. Lebih lanjut Ali Mukhayat menulis bahwa dalam masa tiga bulan di Tapaktuan, sudah berpuluh orang yang membenarkan Ahmadiyah dan beratus orang yang bersimpati (Mughayat, 2000: 3)

Namun, di dalam buku tersebut tidak disebutkan siapa saja orang-orang yang membenarkan dan kemudian bergabung dalam Jemaat Ahmadiyah Qadiani. Tidak dijelaskan pula siapa saja orang-orang yang bersimpati terhadap pergerakan Jemaat Ahmadiyah Qadiani di wilayah tersebut. Satu hal yang patut dicatat sebagai kritik atas sumber tersebut bahwa sumber tersebut tidak secara jelas memberikan penjelasan yang semestinya harus diungkap, mengingat penulis buku tersebut merupakan anggota dari Jemaat Ahmadiyah Qadiani, sehingga dari segi sumber penulisan seharusnya akan lebih mudah untuk mendapatkannya.

Penulisan yang terkait dengan jumlah orang-orang yang membenarkan dan bersimpati menjadi sebuah penulisan yang dapat dianggap hanya sebagai klaim sepihak saja dengan tujuan untuk menciptakan prestise bagi Jemaat Ahmadiyah Qadiani bahwa dari perdebatan yang dilakukan, berakibat semakin banyaknya anggota dan simpatisan kelompok ini. Jika tanpa disertai dengan bukti-bukti yang memadai, maka penulisan buku tersebut kurang lengkap

Peneliti baru menemukan nama orang-orang yang membenarkan Jemaat Ahmadiyah Qadiani pada buku yang ditulis oleh Iskandar Zulkarnain (Zulkarnain, 2005). Mereka yang bergabung dengan Jemaat Ahmadiyah Qadiani antara lain : Abdul Rahman, Muhammad Syam, Mahdi Sutan Singasoro, Mamak Gamuk, Munir, Ali Sutan Marajo, Sulaeman, Datuk Dagang Muhammad Hasan, Abdul Wahid, Muhammad Yakin Munir, Nyak Raja, Abbas dan Teuku Nasruddin. Dari beberapa nama yang telah disebutkan, kita dapat mengindikasikan beberapa nama yang kebanyakan menggunakan nama-nama etnis Minang. Hal ini tidaklah mengherankan, di mana orang-orang yang belajar ke Qadian, India pertama kali adalah orang-orang Sumatera Thawalib yang berada di Sumatera Barat.

Selanjutnya, perkembangan Jemaat Ahmadiyah Qadiani di wilayah Medan juga mengalami nasib yang sama. Dari beberapa buku, baik yang dikeluarkan oleh Jemaat Ahmadiyah Qadiani sendiri, maupun bukubuku non Jemaat Ahmadiyah Qadiani, tidak dapat ditemukan secara jelas, karena hanya sampai kepada masuknya Jemaat Ahmadiyah Qadiani di wilayah ini.

Semangat yang dahulu digelorakan oleh proklamator gerakan ini, Mirza Ghulam Ahmad untuk berepistemologi telah menghilang di dalam diri setiap Ahmadi. ${ }^{6}$ Motivasi menulis, terutama untuk merawat catatancatatan penting yang terkait dengan sejarah perkembangan Jemaat Ahmadiyah Qadiani di wilayah Medan-Aceh telah berangsurangsur lenyap dari bumi pemikiran orangorang Ahmadiyah Qadiani di wilayah ini. Hal ini memiliki dampak yang sangat besar dalam mengembangkan gerakan ini, karena

6 Sebutan bagi Anggota Jemaat Ahmadiyah Qadiani. 
pondasi awal akan pentingnya jihad melalui pena yang telah diciptakan oleh Mirza Ghulam Ahmad sedikit demi sedikit telah menghilang di dalam khasanah pemikiran orang-orang Ahmadi. Pembatalan jihad berupa perang yang digantikan dengan pena menjadi tak berarti dalam khazanah pemikiran orang-orang Ahmadiyah, khususnya di wilayah Medan-Aceh.

Mereka hanya dapat menjadi manusiamanusia yang tidak memiliki kreativitas dalam kajian-kajian ilmiah seperti ini. Orangorang yang tergabung di dalam jemaat ini terlihat hanya menunggu arahan dari kantor pusat, walaupun kantor pusat sendiri juga memiliki keterbatasan dalam hal penulisan. Ini merupakan dampak dari ketaatan yang terlalu berlebihan. Keinginan untuk menulis menjadi terhambat, karena sistem sentralistik yang tidak pada saatnya lagi dilaksanakan di dalam dunia yang semakin berkembang ini, malah menjadi dasar pemerintahan kekhalifahan versi Jemaat Ahmadiyah Qadiani, sehingga walaupun dengan alasan yang berbeda, tak urung Sutan Takdir Alisyahbana beranggapan negatif terhadap khilafah. $^{7}$

Buku-buku yang bersifat lokal tentang perkembangan Jemaat Ahmadiyah Qadiani di masa-masa penjajahan Belanda tidak dapat ditemukan, dengan alasan semua buku dan data-data di zaman itu sudah menghilang atau dengan alasan semuanya ada di kantor pusat (wawancara Ibnu Muhyidin, Juni 2007). Hal ini sangat berbeda dengan organisasi lainnya seperti Muhammadiyah yang memiliki buku-buku yang terkait dengan sejarah yang lebih lengkap tentang perkembangan pergerakannya.

7 Sutan Takdir Alisyahbana mengatakan bahwa kekhalifahan sebaiknya dihapuskan saja karena menimbulkan perselisihan di kalangan umat. Pernyataan ini diucapkan saat kunjungan perwakilan Jemaat Ahmadiyah Qadiani ke kediaman Sutan Takdir Alisyahbana pada tanggal 15 November 1982.
Untuk menyebarkan ajaran Jemaat Ahmadiyah Qadiani di Medan, pada tahun 1930, Maulana Rahmat Ali HA. OT menunjuk Maulana Sadiq HA. Barakatullah, sedangkan Maulana Rahmat Ali, meneruskan perjalanannya sampai keluar Sumatera (Arsip Jemaat Ahmadiah Indonesia 1996).

Tahun masuknya Jemaat Ahmadiyah Qadiani dijadikan rujukan sebagai tahun berdirinya Jemaat Ahmadiyah Qadiani di Medan. Pada saat itu, kegiatan Jemaat seperti shalat dan pengajaran agama masih diadakan di rumah-rumah (wawancara tokoh, 17 Juli 2007). Pada saat itu, secara organisatoris antara Medan-Aceh belum memiliki keterikatan satu sama lain. Artinya, secara kelembagaan masih terpisah. Ini berbeda dengan tahun-tahun berikutnya, di mana telah terbentuk secara kelembagaan Jemaat Ahmadiyah wilayah Medan-Aceh, dan juga wilayah yang lebih besar lagi meliputi Sumut-Aceh atau juga Sumbagut, meliputi Aceh, Sumatera utara, Riau dan Sumatera Barat. Berturut-turut mubaligh Jemaat Ahmadiyah Qadiani yang ditugaskan di wilayah Medan-Aceh antara lain : Maulana Muhammad Sadiq H.A bin Barakatullah (Medan), Abu Bakar Ayyub H.A ${ }^{8}$, Sulaiman Abbas, Muhyiddin Syah, Khoiruddin Barus, H.A Basit, Maksum Ahmad, Syamsir Ali, Ibnu Muhyiddin (wawancara dengan Nasboon Muhammad).

Perkembangan Jemaat Ahmadiyah memiliki titik cerah pada masa Orde Baru, di bawah kepemimpinan Soeharto, walaupun pada masa ini dikeluarkan fatwa MUI tentang Ahmadiyah (Kumpulan Fatwa dan Hukum MUI, 1989:1-11), namun secara kuantitas, perkembangan Jemaat Ahmadiyah Qadiani semakin nampak terlihat. Hal ini didasari oleh berdirinya sebuah mesjid di Jalan Pasar III No.5 A Glugur Darat. ${ }^{9}$

8 Tiga orang pertama adalah mubaligh pada masa 19301945 cabang Medan.

9 Pernyataan ini didasari oleh pengakuan Mubaligh Jemaat Ahmadiyah Qadiani Ibnu Muhyiddin bahwa berdirinya 
Nasboon Mahmud menjelaskan bahwa pada tahun 1953, aktifitas Jemaat ini dilakukan di sebuah rumah sewaan di jalan Pancowati No. 8 Medan. Shalat lima waktu, Shalat Jum'at dan pengajaran agama dilakukan di rumah sewaan ini, dengan harga sewa Rp 8,-. Baru kemudian, pada tahun 1964 mulai dilakukan pembangunan mesjid seperti yang telah disebutkan di atas, dan pembangunan tersebut dapat diselesaikan pada tahun 1975. Pembangunan mesjid tersebut merupakan hasil swadaya bersama para anggota yang berjumlah puluhan orang dan juga bantuan dari Pengurus Besar Jemaat Ahmadiyah Qadiani Indonesia (wawancara dengan Nasboon Mahmud, 27 Juli 2007). Dengan berdirinya mesjid Mubarak, Jemaat Ahmadiyah Qadiani semakin gencar dalam melakukan sosialisasi tentang pemikiran dan ajarannya pada masa-masa selanjutnya.

\section{b. Periode Pertama Orde Baru 1968-1982}

Jemaat Ahmadiyah cabang Aceh pada periode ini belum mengalami perkembangan. Perkembangan Jemaat Ahmadiyah hanya berkutat di wilayah Medan dan sekitarnya, walaupun masuknya Jemaat Ahmadiyah Qadiani di Tapaktuan, Aceh. Jemaat Ahmadiyah Qadiani Wilayah Medan hanya mengkordinir daerah yang berada di sekitarnya.

Perkembangan Jemaat Ahmadiyah Qadiani di Medan mulai dirasakan semakin menggeliat dengan adanya usaha untuk membangun sebuah mesjid, yang dapat dijadikan sebagai pusat penyebaran misi Jemaat Ahmadiyah Qadiani. Proses pembangunan mesjid terkesan lambat, karena faktanya, mesjid baru dapat berdiri dengan kokoh pada tahun 1975. Pembangunan mesjid terkesan lambat karena adanya permintaan penghentian pembangunan oleh pemerintah setempat atas permintaan masyarakat se-

sebuah mesjid harus berdasarkan kebutuhan sehingga mesjid yang kami dirikan tidak seperti mesjid lainnya, yang pada umumnya sepi tak memiliki jama'ah, wawancara Selasa, 17 Juli 2007, pkl 11.00-12.15 WIB. kitar wilayah berdirinya mesjid, yang merasa resah dengan berdirinya mesjid Jemaat Ahmadiyah Qadiani ini. Namun, dengan semangat yang semakin membaja di kalangan Jemaat Ahmadiyah Qadiani, pembangunan mesjid dapat dilanjutkan, walaupun penyelesaiannya harus diawali melalui proses hukum. Dalam proses hukum ini, Jemaat Ahmadiyah Qadiani dapat memenangkan sengketa ini, dan pemerintah setempat harus membayar ganti rugi sebesar Rp 550.000,-10 sejumlah uang yang sangat besar ketika itu.

Gambaran sejarah ini menunjukkan betapa sebuah negara hukum tidak berjalan pada koridor hukum yang sebenarnya. Padahal, Pancasila dan Undang-undang Dasar 1945 memberikan peluang bagi setiap manusia Indonesia untuk menjalankan agama dan kepercayaannya. Namun, permasalahannya, Jemaat Ahmadiyah Qadiani telah menggunakan bendera Islam, walaupun secara pemikiran dan ajaran yang terkait dengan hal-hal yang prinsip seperti kenabian Mirza Ghulam Ahmad, sangat berbeda dengan muslim kebanyakan. Dengan pemikiran dan ajaran yang sangat berbeda tersebut, seharusnya Jemaat Ahmadiyah Qadiani tidak menggunakan bendera Islam dalam proses perkembangannya. Pemikiran dan ajaran yang dikembangkan oleh Jemaat Ahmadiyah Qadiani dianggap menodai ajaran Islam, sehingga tidaklah mengherankan jika masyarakat dan pemerintahan setempat melarang pembangunan mesjid Jemaat Ahmadiyah Qadiani.

Setelah berdirinya Mesjid, maka seluruh aktifitas Jemaat Ahmadiyah Qadiani, seperti shalat lima waktu, shalat tahajud dan pengajaran agama dilakukan di sini. Anggota yang datang ke mesjid ini sebagian besar berasal dari Belawan, Kampung Lalang dan

10 Wilayah tempat mendirikan mesjid pada periode 1964 masih belum terdapat pemukiman penduduk. Masyarakat yang menolak adalah masyarakat yang bermukim di luar daerah ini, yang didukung oleh beberapa organisasi Islam. 
wilayah Medan lainnya. Anehnya, orangorang di sekitar Mesjid enggan untuk melaksanakan shalat di Mesjid tersebut. Apabila dirunut ke belakang, ini merupakan dampak dari pelarangan berdirinya Mesjid sebelumnya. Di mesjid ini juga dilakukan pengajaran agama yang dilakukan secara bergantian karena belum memiliki mubaligh yang diutus oleh pengurus pusat Jemaat Ahmadiyah Qadiani. Pengajaran agama dilakukan secara teratur oleh salah seorang yang diangkat sebagai mubaligh lokal, yaitu Ahmad Hariadi (wawancara Nasboon Mahmud, 27 Juli 2007). ${ }^{11}$ Dengan gencar, pemahaman dan pemikiran Jemaat Ahmadiyah Qadiani diajarkan kepada seluruh anggota Jemaat.

Pada tahun 1979 Jemaat Ahmadiyah Qadiani mengadakan konfrensi pers dalam memperingati 100 tahun berdirinya Jemaat Ahmadiyah Internasional. Konfrensi Pers ini dilakukan pada tanggal 20 April 1979 di Medan. Hadir sebagai pembicara yaitu Saleh A. Nahdi, yang didampingi oleh M. Muhyiddin Syah (mubaligh) dan Nasboon Mahmud, SH.

Konferensi Pers juga dilakukan di Medan pada tanggal 18 September 1982 di rumah M. Rasyid, sekretaris Tabligh Jemaat Medan, yang dihadiri oleh 10 wartawan surat kabar Harian dan Mingguan, RRI dan TVRI Medan. Dalam wawancara ini, Raisut-Tabligh Nasional dan sekretaris Umur Kharijiyah I Pengurus Besar memberikan keterangan tentang kegiatan dan misi jemaat Ahmadiyah Qadiani (Surat Edaran Khusus No. 53, 31 Desember 1982:6).

Dalam khazanah penulisan, Jemaat Ahmadiyah Qadiani menjadikan sarana ini menjadi cara untuk melakukan pendekatan dengan orang-orang di luar Ahmadi-

11 Dalam perkembangan selanjutnya, dengan tidak menjelaskan tahun, Nasboon Mahmud menjelaskan bahwa Ahmad Hariadi menjadi orang yang gila. Ahmad Riadi mengadakan mubahalah (doa saling melaknat) dengan Khalifatul Masih Jemaat Ahmadiyah Qadiani. yah Qadiani. Mereka melakukan pameran Literatur hasil tulisan orang-orang Ahmadiyah, disertai dengan penyebaran brosur untuk mensosialisasikan pemikiran Jemaat Ahmadiyah Qadiani kepada khalayak. Bertempat di Gedung Juang 45 Medan, tanggal 3 Mei 1981 berlangsung "Tabligh Umum" dengan topik tunggal "Jemaat Ahmadiyah Indonesia mengisi Abad XV Hijriyah", di mana Mubaligh M. Abdul Hayee HP selaku juru bicara. Acara ini dihadiri oleh 200 undangan, baik anggota jemaat maupun non-anggota Jemaat. Selain itu, acara tabligh umum ini dirangkai dengan pameran buku-buku dan foto-foto kegiatan serta perkembangan Ahmadiyah di dalam dan luar negeri (Surat Edaran Khusus No. 13, 1 Juni 1981:7).

Kegiatan Jemaat Ahmadiyah Qadiani di wilayah Medan tidak hanya sampai di situ. Hubungan baik dengan instansi pemerintah pun dilakukan pada periode ini. Kunjungan dilakukan oleh Mubaligh M. Abdul Hayee HP dan Nasboon Mahmud ke kantor DPRD Tk. I Sumatera Utara, kantor DPRD Tk. II Kodya Medan, Kantor Pangdam II Bukit Barisan, Kepala Pengadilan Negeri di Medan dan Rektor IAIN Medan (Surat Edaran Khusus No. 13, 1 Juni 1981:7).

Pada periode ini, sosialisasi yang dilakukan oleh Jemaat Ahmadiyah Qadiani dilakukan melalui konferensi Pers, pameran buku, kunjungan terhadap tokoh dan instansi pemerintahan, serta pengajaran agama rutin yang dilakukan di Mesjid Jemaat Ahmadiyah Qadiani Pasar III yaitu Mesjid Mubarak.

Secara kuantitas, anggota Jemaat Ahmadiyah Qadiani belum mengalami perkembangan yang cukup berarti. Jumlah anggota Jemaat Ahmadiyah Qadiani hanya berkisar puluhan orang (Wawancara Hasboon Mahmud, 27 Juli 2007). Kegiatan-kegiatan yang dilakukan oleh Jemaat Ahmadiyah Qadiani tidak memiliki dampak yang berarti, karena secara kuantitas, keanggotaan hanya berjumlah puluhan orang. Hal ini 
mungkin disebabkan oleh dikeluarkannya fatwa Majelis Ulama Indonesia pada tahun 1980 bahwa Jemaat Ahmadiyah Qadiani merupakan kelompok di luar Islam. Tidak mengherankan jika kita mengaitkan fatwa ini dengan perkembangan Jemaat Ahmadiyah Qadiani pada periode awal Orde Baru ini, walaupun pemerintah Orde Baru sendiri tidak memiliki respon yang cukup berarti terhadap kelompok ini, namun masyarakat sepertinya lebih meyakini fatwa yang dikeluarkan oleh ulamanya.

Pemerintah Orde Baru dan bahkan pemerintahan Soekarno malah memberikan kesempatan yang lebih besar karena secara hukum, Jemaat Ahmadiyah Qadiani terdaftar secara sah dan meyakinkan, berdasarkan Penetapan Menteri Kehakiman No. JA. 5/23 tanggal 13 Maret 1953, sehingga dalam melakukan gerakan dakwahnya, tidak dapat dijerat sanksi hukum yang berarti. Pancasila dan Undang-undang Dasar 1945 juga memberikan ruang yang terbuka bagi perkembangan setiap gerakan keagamaan maupun kepercayaan.

\section{c. Periode Kedua Orde Baru, 1982-1985}

Pada periode ini, Jemaat Ahmadiyah wilayah Medan mulai mengalami perkembangan yang cukup berarti. Peningkatan pengajaran terhadap setiap anggota Jemaat Ahmadiyah Qadiani sangat gencar dilakukan. Kurikulum pengajaran untuk seluruh Jemaat berdasarkan kelompok umur telah selesai disusun di tingkat Nasional. Pelaksanaannya dilaksanakan oleh setiap cabang di seluruh Indonesia, tak terkecuali di wilayah Medan dan sekitarnya. Untuk wilayah Medan dan sekitarnya, kurikulum pendidikan yang baru ini terdapat di dalam kegiatan Pra-Madrasah bagi remaja dan anak-anak, yang dilakukan di Mesjid Mubarak. Pembacaan daras setelah selesai shalat Maghrib dan Shalat Subuh senantiasa dilakukan. Setiap harinya, hadis-hadis dan pembacaan Al-Qur'an dilaksanakan di mesjid Jemaat Ahmadiyah Qadiani wilayah Medan.

Kegiatan-kegiatan amal juga dilakukan oleh Jemaat Ahmadiyah Qadiani wilayah Medan. Pada tanggal 17 Maret 1989, Jemaat Ahmadiyah Qadiani melaksanakan kunjungan ke Panti Asuhan Al-Washliyah P. Brayan dan Panti Asuhan Al-Washliyah di Jl. Ismailiyah Medan. Kunjungan ke Panti Asuhan tersebut diisi dengan pemberian beberapa kebutuhan pokok, seperti: $75 \mathrm{Kg}$ Beras, $20 \mathrm{~kg}$ gula pasir dan $10 \mathrm{Kg}$ kacang hijau (Mughayat, 2000: 170).

Pada periode ini, Jemaat Ahmadiyah Qadiani juga mulai melebarkan sayapnya di wilayah Aceh. Satu nama yang disebut-sebut dalam laporan akhir tahun 1982-1983 adalah Eddy Wanda dari Meulaboh (Laporan Akhir Tahun Jemaat Ahmadiyah Indonesia 1982-1983: 17). Ia merupakan satu-satunya anggota Jemaat Ahmadiyah yang dengan gencar melakukan sosialisasi tentang Jamaat Ahmadiyah Qadiani.

Dari fakta-fakta yang diuraikan di atas, tampak jelas betapa bersemangatnya Jemaat Ahmadiyah Qadiani wilayah Medan melakukan sosialisasi kepada orang-orang di luar mereka. Dengan keyakinan yang mereka miliki, mencoba merengkuh nurani dengan kegiatan-kegiatan amal. Perbaikan dalam organisasi pun gencar dilakukan, yang diawali dengan perbaikan kurikulum pendidikan bagi anggotanya.

\section{d. Periode Ketiga Orde Baru, 1985-1998}

Salah satu usaha terpenting dalam pembaharuan politik pada masa Orde Baru adalah penetapan Pancasila sebagai satu-satunya asas bagi semua organisasi politik dan organisasi kemasyarakatan. Ide untuk menjadikan Pancasila sebagai satusatunya asas disampaikan pada waktu pidato kenegaraan Presiden Soeharto 17 Agustus 1982. Titik puncaknya yaitu ketika ditetapkannya Pancasila sebagai satu-satunya asas bagi organisasi politik dan kemasya- 
rakatan melalui TAP MPR No 8 Tahun 1985. Penetapan ini dimungkinkan untuk dapat mencegah terjadinya konflik ideologi antar organisasi, sehingga suasana baru dalam kehidupan berbangsa dan bertanah air dapat terwujud. Persatuan dan kesatuan segenap elemen dapat tercapai, sehingga masingmasing pihak tidak lagi menganggap bahwa ideologinyalah yang paling benar.

Penetapan ini pada awalnya mendapat tantangan dari berbagai pihak. Dengan pemberlakuan asas tunggal ini, demokrasi dianggap telah mati. Aspirasi masing-masing kelompok dianggap tidak tersalurkan. Namun, dengan berjalannya waktu, Pancasila sebagai satu-satunya asas mulai diterima oleh kelompok-kelompok yang ada, terlebih lagi kelompok-kelompok Islam (Alfian dan Sjamsuddin, 1988: 40-41). Jemaat Ahmadiyah Qadiani merupakan salah satu kelompok yang menerima asas tunggal Pancasila tersebut. Jemaat Ahmadiyah adalah suatu ormas yang berdasarkan agama Islam dan ajaran pendirinya Hadhrat Mirza Ghulam Ahmad, tunduk pada semua UndangUndang Negara dan Peraturan Pemerintah RI khususnya UUD 1945 seutuhnya. Sejak ditetapkan melalui Ketetapan Menteri Kehakiman Republik Indonesia, Jemaat Ahmadiyah Qadiani telah menganut faham asas tunggal Pancasila. Lebih lanjut Ketua PB Jemaat Ahmadiyah Qadiani, Ir. Syarif Ahmad Lubis (Mughayat, 200: 339). mengatakan bahwa sesuai dengan itu, Jemaat Ahmadiyah Qadiani akan mencantumkan Pancasila sebagai asas tunggal dalam anggaran dasarnya secara tertulis, berhubung akan dilaksanakan dan disesuaikan segera setelah UndangUndang Ormas diumumkan Pemerintah.

Hal ini merupakan intrepetasi dari pernyataan Basyir Ahmad, adik dari Mirza Basyiruddin Mahmud Ahmad. Ia berkata :

“Orang-orang Ahmadi di Indonesia setia kepada Indonesia, kaum Ahmadi di Siria setia kepada Siria, Orang-orang Ahmadi di Mesir setia kepada Mesir, kaum Ahmadi di Afrika Barat setia kepada pemerintah mereka masing-masing. Orang-orang Ahmadi di Jerman loyal kepada Jerman. Kaum Ahmadi di Inggris setia kepada Inggris. Di Amerika setia kepada Amerika dan begitu seterusnya. Ini perintah Tuhan dan suara hati nurani kami. Dan orang yang tidak percaya kepada kami dan menisbatkan beberapa kepercayaan lain kepada kami adalah menghina Tuhan dan berbuat kesalahan besar terhadap kami."

Kesetiaan kepada negara di mana Jemaat Ahmadiyah Qadiani berada merupakan bukti loyalitas mereka kepada Tuhan. Sebagai bentuk kesetiaan itu, Jemaat Ahmadiyah Qadiani harus menerima segala perundangundangan maupun dasar negara yang dianut oleh negaranya. Dalam kaitannya dengan hal itu, maka Jemaat Ahmadiyah Qadiani berusaha untuk menunjukkan kesetiaannya kepada bangsa dan negara Indonesia, dengan cara menerima dan menggunakan asas Pancasila sebagai asas mereka.

Hal ini berbeda dengan kelompokkelompok umat Islam yang dengan tegas menjadikan Islam sebagai asas dari organisasi mereka. Kelompok-kelompok tersebut menyadari bahwa Islam merupakan ajaran yang telah sempurna. Sebagai ajaran yang telah sempurna, Islam melingkupi pelbagai dimensi kehidupan. Mereka memahami bahwa Islam tidak terbatas pada berbagai ritual ibadah yang bersifat rohaniyah saja. Islam tidak dipahami dengan pemahaman yang sempit itu, sehingga sebagai ajaran yang paripurna, tentunya melingkupi berbagai sistem kehidupan. Oleh karena itu, sebagai sebuah sistem, Islam harus dijadikan asas dalam setiap kelompok yang ingin memperjuangkan Islam. Ia harus diformalkan dalam bentuk yang lebih nyata yaitu asas Islam atau ideologi Islam.

Islam adalah sebuah sistem nilai yang komprehensif mencakup seluruh dimensi 
kehidupan. Dia memberi petunjuk bagi kehidupan manusia dalam semua aspeknya, dan menggariskan formulasi sistemik yang akurat tentang hal itu. Ia sanggup memberi solusi atas berbagai masalah vital dan kebutuhan akan berbagai tatanan untuk mengangkat harkat kehidupan manusia (Banna, 1997: 26-37). Sangat berbeda sekali tentunya dengan Jemaat Ahmadiyah Qadiani yang menggunakan asas Pancasila sebagai dasar bagi organisasinya.Jika kita mencoba menganalisa tentang kenyataan ini, merupakan suatu hal yang wajar jika Jemaat Ahmadiyah Qadiani memiliki pemikiran yang berbeda dengan kelompok Islam kebanyakan.

Namun, alangkah naifnya jika kita ingin memperjuangkan tegaknya Islam, kita sendiri malah menanggalkan Islam sebagai ideologi gerakan kita. Jika kita memahami bahwa Islam merupakan sebuah ajaran yang telah sempurna, maka kita juga harus meyakini bahwa Islam juga merupakan dasar dari setiap pemikiran kita. Islam sebagai ideologi harus tertanam dalam pemikiran kita dan berusaha memperjuangkannya, sehingga dengan tegaknya ideologi Islam tersebut, maka umat Islam akan dengan mudah menjalankan agamanya secara sempurna. Nurcholis Madjid (Panji Masyarakat No. 687, 21-30 Juni 1991:22) mengungkapkan bahwa konstitusi Madinah merupakan rumusan tentang prinsip kesepakatan antara muslim Yastrib di bawah Rasulullah dengan berbagai kelompok non muslim kota itu untuk membangun masyarakat secara bersama-sama. Kebebasan beragama diatur sesuai dengan kepercayaan dan keyakinannya masingmasing, hidup bersama dalam semangat kebersamaan. Hal ini menjelaskan kepada kita bahwa Muhammad bin Abdullah juga memberikan gambaran bahwa untuk memperjuangkan Islam, umat Islam harus menjadikan Islam sebagai asas dalam perjuangannya. Dengan diberlakukannya konstitusi Madinah, umat Islam dapat menjalankan
Islam secara paripurna, karena di dalam konstitusi tersebut, umat Islam dibatasi oleh Islam itu sendiri sebagai asasnya.

Pemikiran Jemaat Ahmadiyah Qadiani tentang hal ini dilakukan untuk mendekatkan Jemaat mereka kepada setiap pemerintahan yang berkuasa di setiap negara. Dengan adanya kedekatan dengan penguasa maka akan dapat mempermudah Jemaat ini untuk menyebarkan pengaruhnya. Jadi, asas kelompok ini berdasarkan negara masingmasing, dan tentunya Jemaat Ahmadiyah Qadiani di China atau negara-negara komunis tentunya menggunakan asas komunis jika Jemaat Ahmadiyah Qadiani konsisten dengan pemahaman yang mereka miliki. Selain penggunaan asas tunggal tersebut, Jemaat Ahmadiyah Qadiani pada periode ini masih menggunakan metode yang sama seperti periode sebelumnya, yaitu melakukan kegiatan-kegiatan amal dan pengajaran kepada anggotanya.

Pada periode ini, Jemaat Ahmadiyah Qadiani wilayah Medan mengalami perkembangan yang cukup baik. Bahkan, secara kelembagaan wilayah Medan menjadi lebih luas sehingga menjadi wilayah Medan-Aceh. Jumlah anggotanya mengalami peningkatan bila dibandingkan dengan periode sebelumnya. Pada awal 1985-1986, anggotanya hanya berkisar delapan keluarga saja. Namun, pada tahun 1987-1988 jumlah anggotanya mencapai 537 orang (Laporan Umum Jemaat Ahmadiyah Qadiani 19871988: 33).

Tirmizi Ali menjelaskan bahwa Jemaat Ahmadiyah Qadiani cabang Banda Aceh dibentuk pada Oktober 1992 (wawancara Sekretariat Tabligh Jemaat Ahmadiyah Qadiani Banda Aceh, 17 Juli 2007), setelah sebelumnya juga telah dibentuk Jemaat Ahmadiyah Qadiani cabang Lhokseumawe pada tahun 1990 (wawancara mubaligh cabang Lhokseumawe, 17 Juli 2007). Gambaran tentang kondisi Jemaat Ahmadiyah Qadiani di wilayah Aceh ini 
tidak dapat dijelaskan secara spesifik karena data-data yang ada tenggelam bersama ribuan manusia akibat gempa dan tsunami yang melanda Aceh pada Desember 2001.

Adapun yang masih dapat ditemukan adalah susunan pengurus cabang yang terdiri dari :

Ketua : Abd. Hamid Djas (Pegawai Dinas Sosial)

Sekum : (Alm) Salman Al-Farisi (PegawaiPerhubungan Laut)

Sek. Mal (Bendahara) : Afid Supriatna, SH (Pegawai Emigrasi Banda Aceh).

Sek. Tabligh : Tarmizi Ali

Sek. Tarbiyat : Ghulam Hamdani

Jumlah anggota Jemaat Ahmadiyah Qadiani cabang Banda Aceh dan Lhokseumawe juga tidak dapat dipastikan. Tarmizi Ali dan Sarmad Ahmad menjelaskan bahwa jumlah anggota Jemaat Ahmadiyah Qadiani cabang Banda Aceh berkisar 13 orang dan anggota Jemaat Ahmadiyah Qadiani cabang Lhokseumawe berjumlah 12 orang. Kegiatan yang dilakukan pun tidak terlampau banyak. Untuk mensosialisasikan Jemaat Ahmadiyah Qadiani, mereka melakukan tabligh dari pintu ke pintu. Menyampaikan tentang ajaran yang dibawa oleh Mirza Ghulam Ahmad sehingga masyarakat tertarik untuk bergabung bersama Jemaat Ahmadiyah Qadiani.

Untuk membina anggotanya, Jemaat Ahmadiyah cabang Aceh melakukan kegiatan yang dilakukan di sebuah rumah. Hal ini dilakukan karena belum memiliki mesjid. Mereka belum merasa membutuhkan mesjid sebagai pusat pergerakannya karena jumlah mereka yang masih relatif sedikit.Pembinaan dilakukan dengan melakukan bersama-sama Shalat Jum'at, Shalat lima waktu dan shalatshalat sunat lainnya. Pengajaran agama juga tidak ketinggalan dilakukan sebagai kewajiban, walaupun belum terdapat mubaligh yang diutus dari kantor pusat.
Untuk wilayah Medan sendiri, kegiatan yang dilakukan hampir sama seperti periode sebelumnya. Kegiatan-kegiatan amal dan pertemuan dengan berbagai tokoh serta instansi terkait kerap dilakukan. Dalam kegiatan tahunan Jalsah Salanah lokal, Jemaat Ahmadiyah Qadiani melaksanakan kegiatan donor darah pada tanggal 15 Juli 1990 di halaman mesjid Mubarak Medan. Jumlah peserta yang mendonorkan darahnya sebanyak 29 orang. Kegiatan-kegiatan untuk mengisi hari-hari besar pun dilakukan oleh Jemaat Ahmadiyah Qadiani, seperti perayaan Isra' Miraj, Maulid Nabi Muhammad dan Rajaban yang merupakan peringatan seabad pergerakan Jemaat Ahmadiyah Qadiani.

Pada periode ini, pembinaan terhadap anggota melalui berbagai jalur pendidikan, baik yang formal seperti pramadrasah, maupun yang informal seperti pengajian, ceramah, khutbah dan lain-lain dilakukan secara intensif. Rumah Missi/ Mubaligh dan rumah untuk tamu didirikan sebagai sarana pendukung untuk peningkatan dan perkembangan Jemaat Ahmadiyah Qadiani. Rumah ini digunakan sebagai tempat tinggal para Mubaligh yang diutus untuk menyampaikan missi Jemaat Ahmadiyah Qadiani di wilayah Medan-Aceh.

Stasiun Televisi MTA yang berpusat di London sudah mulai dapat dinikmati oleh Jemaat Ahmadiyah Qadiani di wilayah Medan-Aceh. Informasi seputar Perkembangan Jemaat Ahmadiyah Qadiani di seluruh dunia dapat diperoleh melalui stasiun televisi internasional ini. Kegiatan Bai'at internasional dapat disaksikan secara langsung tanpa gangguan yang berarti. Setiap anggota Jemaat Ahmadiyah Qadiani dapat secara langsung mendengarkan ceramah maupun khotbah dari khalifahnya di London, Inggris, sehingga memberikan motivasi yang sangat besar dalam usaha mengembangkan Jemaat Ahmadiyah Qadiani di wilayah Medan-Aceh. 


\section{PENUTUP}

Walaupun Jemaat Ahmadiyah Qadiani telah melebarkan sayapnya di wilayah Medan pada tahun 1930, namun Jemaat ini mengalami pertumbuhan sejak berdirinya Mesjid Mubarak di Jalan Pasar III No. 5A, Glugur Darat pada tahun 1975. Sehingga periode ini dianggap sebagai fase pertumbuhan Jemaat Ahmadiyah Qadiani wilayah Medan-Aceh.

Jemaat Ahmadiyah Qadiani mengalami perkembangan yang relatif stagnan pada periode kedua Orde Baru, dengan jumlah anggota puluhan orang. Hal ini terkait fatwa Majelis Ulama Sumatera Utara yang menyatakan bahwa Jemaat Ahmadiyah Qadiani merupakan kelompok di luar Islam, sehingga menciptakan jarak yang tak terbatas antara anggota Jemaat dengan orang-orang Islam lainnya.

Pada periode ketiga Orde baru, Jemaat Ahmadiyah Qadiani mengalami perkembangan yang berarti secara kuantitas maupun dalam hal organisasi. Jumlah anggotanya yang terdaftar sebanyak 537 orang. Hal ini terjadi karena pada periode ini, Jemaat Ahmadiyah melakukan beberapa strategi sosialisasi terkait dengan ajaran yang dipahami oleh Jemaat Ahmadiyah Qadiani. Pada periode ini, wilayah Aceh juga mendapat pengaruh, sehingga pada periode ini, wilayah Medan meluas meliputi wilayah Aceh yang mulai mengalami pertumbuhan dengan berdirinya Jemaat Ahmadiyah Qadiani secara kelembagaan pada tahun 1992.

Penelitian lebih lanjut mengenai Jemaat Ahmadiyah Qadiani harus terus dilakukan. Hal ini menjadi kewajiban dan tantangan tersendiri bagi para peneliti sejarah dan kebudayaan untuk mengungkap sejarah sebuah gerakan pemikiran dan keagamaan di Indonesia dengan keterbatasan sumber yang ada.

\section{DAFTAR SUMBER}

Abdullah, Taufik dan Sharon Siddique. 1989. Tradisi dan Kebangkitan Islam di Asia Tenggara. Jakarta : LP3ES.

Ahmad Pontoh, Zafrullah. 1984. Imbauan Hati Nurani. Jakarta : Jemaat Ahmadiyah Indonesia)

Alfian dan Nazaruddin Sjamsuddin. 1988. Masa Depan Kehidupan Politik Indonesia. Jakarta : AIPI.

Ali, Mukti. 1971. Alam Pemikiran Modern di Indonesia. Jakarta : Yayasan NIDA.

Arsip Jemaat Ahmadiyah Indonesia. 1996.

BrosurJamaah Muslim Ahmadiyah. Sawangan: Jemaat Ahmadiyah Indonesia

Gottchalk, Louis. 1995. Mengerti Sejarah. Terjemahan Nugroho Notosusanto. Jakarta: PT. Tiara Kencana.

Hasan Al-Banna. 1997. Risalah Pergerakan Ikhwanul Muslimin, Terjemahan Anis Matta, et al. Jakarta : Era Intermedia.

J. Donohve, Jhon dan Jhon L. Esposito. 1989. Islam dan Pembaharuan (cetakan II). Jakarta : CV. Rajawali.

Kumpulan Fatwa dan Hukum 1 Majelis Ulama Indonesia Propinsi Sumatera Utara tahun 1989.

Laporan Akhir Tahun Jemaat Ahmadiyah Indonesia 1982-1983.

Laporan Umum Jemaat Ahmadiyah Indonesia 1987-1988.

Kuntowiioyo. 2004. Metodologi Sejarah. edisi kedua. Yogyakarta : PT. Tiara Kencana.

Mirza Ghulam Ahmad as. Nasihat Imam Mahdi \& Masih Mau'ud as mengenai Bai'at. Jakarta : Jemaat Ahmadiyah Indonesia.

Mukhayat, Ali. 2000. Sejarah Pentablighan Jemaat Ahmadiyah Indonesia 19251994. Tasikmalaya : EKB.

Panji Masyarakat No. 687, 21-30 Juni 1991. 
Paul, Johnson, Doyle. 1986. Teori-teori Surat Edaran Khusus No. 50 tanggal 10 Sosiologi Klasik dan Modern. Jakarta : PT. Gramedia.

Pedoman Masyarakat, 20 Januari 1936.

Pergaoelan, 9 Agustus 1932.

Pergaoelan, 19 Agustus 1932.

Pergaoelan, 23 Agustus 1932.

Sinar Islam, nomor Yubelium, Januari 1976

Sujanto, Ahmad. 1985. Psikologi Perkembangan. Jakarta : Aksara Baru.

Surat Edaran Khusus No. 13 tanggal 1 Juni 1981.

Surat Edaran Khusus No. 53 tanggal 31 Desember 1982.

Wawancara. Ibnu Muhyiddin, Mei dan 17 Juli 2007.

Wawancara. Nasboon Mahmud, 27 Juli 2007.

Wawancara. Mubalig cabang Lhokseumawe, 17 Juli 2007.

Wawancara.Sekretariat Tablig Jemaat Ahmadiyah Ahmadiyah Qadiani Banda Aceh, 17 Juli 2007.

Zulkarnain, Iskandar. 2005. Gerakan Ahmadiyah di Indonesia 1925-1942. Jakarta : LK1S. 